\title{
The Value of Competence-based Assessment in Pre-service Teacher Training
}

\author{
Mamsi Ethel Khuzwayo \\ Cape Peninsula University of Technology, Cape Town, South Africa \\ https://orcid.org/0000-0002-4084-8773
}

\begin{abstract}
Given the focus on developing an alternative approach toward improving the quality of teacher education and training in South Africa, teacher educators and curriculum developers face increasing responsibility to implement competence-based assessment in initial teacher education and training. This exploratory examination of the scaffolding assessment of foundational, practical, and reflexive competences conducted through a case study intended to gather data on the experiences, views, and performance of a sample of 42 students in the third-year level of a teacher qualification program. The analytic rubrics with performance descriptors and the rating scale of outstanding, excellent, good, satisfactory, and weak were instruments for gathering quantitative data. The second source of data was face-to-face verbal comments and the diagnostic evaluation conducted by the participants in a focus group on their performance under the codes feedback, feed forward, and feed up in the templates. The analysis of quantitative data presented in the pie chart highlighted different levels of proficiency achieved by participants in foundational, practical, and reflexive competences. The data summarized in the bar chart point to the improvement attained by participants in the focus group. Findings proved that scaffolding assessment into phases allows learners to: regulate their attainment of higher levels of proficiency; work independently; and develop a piece of comprehensive and integrated knowledge, set of skills, and abilities. This study revealed that competence-based assessment is perceived by students to be both an accurate way of gauging their performance and a vital part of the learning process itself.
\end{abstract}

Keywords: Competence-based assessment; teacher-student; perception; learning process

\section{Introduction}

The findings presented in this article are in keeping with the national requirements for the transformation of the curriculum for teacher education and training. The rationale for focusing on the issue of assessment reflects a need to shift away from content-driven assessment, and towards competence-based 
assessment. Theoretical aspects of competence-based teaching, learning, and assessment in higher education have received critical attention in educational research from 1997 after the norms and standards for teacher education and training were introduced. This research sought to establish the principles underlying the practice of competence-based assessment. Thoughts gathered from the pioneers of competence-based assessment and furthermore the guidelines for assessing levels of proficiency promulgated by the South African Qualifications Authority (SAQA) in 2001 and 2011 provided this research with guidelines for planning assessment activities. Even though competence-based assessment is a recommended discourse for evaluating learning and training in higher education, research indicates that the evaluation of the professional and academic performance of students in teacher education and training is still inclined towards the principles of content-based assessment. Researchers have contended that the process of grading students in teacher education focuses on the scores achieved from tests, assignments, and examinations. In this case, the assessors are the ones who provide feedback on the students' attainment. Students do not have a space to reflect on their performance and to learn from their mistakes. The argument in this study is that the continual practice of the contentdriven approach to assessment in teacher education and training deprives students of the opportunities to demonstrate their professional capabilities to the optimal levels of proficiency.

In contrast, the principles of competence-based assessment advocate for: aligning criteria for competent performance; integration of teaching, learning, and assessment; transparency, clarity of focus; validity; and fairness, continuity and consistency, all of which define a different view from traditional methods of assessing performance in teacher education and training. This article endorses an emerging trend in educational practice that favors competence-based assessment for monitoring professional growth and development of teacher education and training in higher education.

This article begins with an examination of the term 'competence' and approaches to assessment adequate for monitoring or measuring progress used to demonstrate competent performance. The article takes into account the principles and models proposed by previous research for planning, developing, and conducting assessment activities, for example, constructive alignment, studentcenteredness, transparency, fairness, and reliability. The conceptual and theoretical framework established in the literature review served as parameters for data analysis and interpretation and discussion of conclusions.

\section{Context of the Study}

The changes introduced in the curriculum for teacher education and training programs enforce the implementation of competence-based teaching, learning, and assessment. The modules and courses should reflect new ways of profiling students' competence performance. The undertaking of this research is part of the initiative to explore the feasibility of integrating teaching, learning, and assessment envisaged in the current curriculum to transform teacher education and training in South Africa. Outcomes-based education and competence-based assessment dominate the narrative about the paradigm shift in teacher education 
and training. The conceptual application of the term initial teacher training in the context of the transformation of teacher education and training refers to the fouryear program for preparing teachers. This concept is used interchangeably with pre-service teacher training in the policy documents of the Department of Higher Education in South Africa.

This study explores the efficacy of scaffolding instruction in the integration of learning and assessment. Traditionally, content-based assessment dominated the assessment procedures in teacher education in South Africa. Critics condemn confining assessments to summative and judgment because students do not get opportunities to reflect on their performance (Whalley, 2014; Boyer \& Bucklew, 2019; SAQA, 2019). This research upholds the view that assessment is an integral part of instruction and learning in the professional training of teachers.

\section{Literature Review}

The conceptual framework for this study draws from two bodies of literature: competence-based assessment and the preparation of teachers for professional practice. Teacher development research has highlighted the proposal for the shift from traditional content-driven assessment to competence-based learning. Competence-based assessment recommends the active participation of students in their learning and assessment through self-reflective practice and selfassessment instead of conforming to the judgments of the lecturers. This study draws upon the two bodies of knowledge to explore the efficacy of competencebased assessment to encourage students to reflect on their performance of learning outcomes set out in the educational studies module.

In the analysis of Navio, Dominguez, and Zagalaz (2019), Misbah, Gulikers, Dharma, and Mulder (2019), Sayed and Kanjee (2013), and Boyer and Bucklew (2019), competence-based teaching, learning, and assessment allow not only the clustering of abilities, skills, and attitudes but also the motivation that is developed gradually all along the education and training process. In the follow up of an assessment of competences in teacher education and training, synthesis of the literature revealed that a competence-based approach is a trend that is adopted internationally (Wesselink, Biemans, Gulikers, Runhaar, \& Mulder, 2018; Gessler \& Peters, 2020; Lassnigg, 2018).

The review of documents and sources produced at the advocacy stages of competence-based education in higher institution of learning in South Africa revealed the definition of concept competence-based assessment as a holistic approach to gathering evidence about the levels profiency students demonstrated to perform abilities, knowledge and skills in a broader sense. The competences are generic statements that articulate the specific abilities, skills, and attitudes concerning professional practice (SAQA, 2019; Department of Higher Education and Training, 2019). The purpose of competence-based education and training in South Africa was to produce able teachers who can solve problems creatively, develop activities, carry out exercises, pose questions, search for relevant information, analyze, understand, and reflect by applying their knowledge in answering the demands of the real work environment. An advocate of the 
adoption of competence-based assessment in teacher education and training in South Africa argued that:

Assessment that catalyzes both teaching and learning can play a role in guiding and supporting the processes aimed at the attainment of applied competence. The response of the South African government to this challenge in higher education is to use assessment formatively and summatively in attaining applied competences. Beets $(2009$, p. 183)

Although competence-based assessment overwhelms local and global research in professional and academic education and training, the literature reveals, however, that there is no complete agreement among scholars and researchers about the exact definition of the term competence. The term competence in this work refers to the broader and more comprehensive description of performance, which is characterized by the professional attributes: independent thinker, lifelong learner, researcher, curriculum developer, and reflective and innovative practitioner (Betts, Huntington, Lao, Dillon, \& Baayard, 2019; Boyer \& Bucklew, 2019). A central premise of competence-based assessment in this view is that proficiency in the professional development must be concerned with the performance of the collective cluster of work-related cognitive abilities, knowledge, and practical skills (Martinez \& Hurtado, 2018; Gessler \& Peters, 2020; Watling \& Ginsburg, 2018).

According to the SAQA (2019) assessment guidelines, higher education and training qualification programs in South Africa should provide a carefully lucid exit-level outcomes curriculum within the framework of competence-based education and assessment. The principle of integrating teaching, learning, and assessment underlies competence-based assessment in professional training in terms of three broad competences: foundational, practical, and reflexive, which are linked to exit-level outcomes for all professional and occupational programs (Beets, 2009; SAQA, 2019). SAQA (2019) indicated that the learning outcomes, which are the pre-determined statements of the envisaged abilities, skills, and knowledge, should link to the assessment criteria.

The body of literature on assessment revealed that there are three perspectives on assessment: content-based assessment, competence-based assessment, and outcomes-based assessments (Black \& William, 2014; Beets, 2009). According to Killen (2015), these three approaches to assessment differ based on programming and principles. Proponents of competence-based assessment assert that competence-based assessment entails careful planning and organization of activities and consistent feedback to ensure that all students master basic-level professional skills, abilities, and knowledge required in the world of professional practice (Van der Vleuten, Sluijsmans, \& Brinke, 2017; Black \& McCormick, 2010; Cebrián, Junyent, \& Mulà, 2020). The body of knowledge about the implementation of competence-based teaching, learning, and assessment asserts that assessment of competences is not a once-off event. Rather, it is a process underpinned by formative principles: consistent feedback, feed forward, and feed up, meaning a process of gradual upward growth moving from the basic level to the level of complexity. The assessment criteria specify the level of the expected standard during the process of monitoring and supervising the attainment of 
proficient development in the training of professional practitioners. The rating scale used to evaluate the progress on the rubrics is a tool used to gather evidence of the progress or milestones towards the achievement of the level of proficient performance (Lassnigg, 2018; Boyer \& Bucklew, 2019; Van Griethuijsen, Kunst, Van Woerkom, Wessenlink, \& Poell, 2019).

\section{Theoretical Framework}

This research drew thoughts and opinions from the scaffolding instructions in the social constructivist theory of learning. The principles of constructivism promote learner-centeredness, active participation, and reflective thinking (Woolfolk-Hoy, 2018; Ornstein \& Hunkins, 2014). The scaffolding model applied in the designing of the assessment activity into three phases and the data collected from the reflective exercise carried out by participants in this research were informed by the model of scaffolding instruction and assessment. The principles of scaffolding instruction and assessment stipulate that monitoring and supervision of growth and development of competences in learning begin with the foundational abilities, knowledge, and skills, and the assessment provides students with information about their progress.

The first level of reflections focused on feedback, where participants used the rubrics to identify gaps under the foundational category of performance of competence, and improved their performance before moving on to the next level. The second level of reflection expected participants to analyze the rubrics to understand the expected acceptable performance at a higher level of proficiency, and this was called feed forward. The last level in this reflection continuum assessed skills, capabilities, and knowledge at the level of complexity, and the focus was on relating performance to diverse settings and situations in the real place of work (Barnett, 2018; Crisp, 2012).

The consideration of the proficiency levels for designing the scaffolding of the assessment activity in this research was to encapsulate the principles of flexibility, reliability, transparency, and fairness. The scaffolding model provided a platform for flexible engagement to participants to learn from mistakes and to utilize those weaknesses to improve their performance to the optimal level of proficiency. According to Van der Vleuten et al. (2017), scaffolding assessment enables individual students to find answers from reflective questions such as: Where am I? (feedback), Where am I going? (feed forward), and Where to next? (feed up).

\section{Methodology and Research Design}

The case study design was preferred for this research. The process of data collection and data analysis utilized quantitative and qualitative procedures. According to MacMillan and Schumacher (2018, p. 26), employing qualitative and quantitative research techniques allows the researcher to use more than one research instrument to collect data in the study. The purpose of the triangulated data collection procedure was for the credibility and validity of the results and findings.

The primary source of data in this research was the results of the quantitative analysis of the levels of proficiency identified in the performance of foundational, 
reflexive, and practical competences by the group of 42 students in the assessment activities. The process of data analysis focused first on elucidating the set of results obtained through the quantitative procedures. The categories of data manifested from the rating scales led to the frequency distribution of data summarized in the pie chart and bar chart (Figures 1 and 2, respectively). A sub-sample of 25 students was used as focus group to solicit qualitative data from reflective exercises and face-to-face verbal comments concerning experiences, views, and opinions on the scaffolding assessment. This data were related to the ratings of their performance. The qualitative data were the yardstick to evaluate participants' perspectives of the competence-based assessment and the possibility of its implementation in preservice teacher training.

\section{Ethical Considerations}

The researcher informed participants in the focus group of the purpose of the assessment activity, which was to explore the benefits of a scaffolding assessment for gauging skills, abilities, and capabilities gained in the process of learning. Participants in the focus group knew that participation was voluntary, and they were entitled to discontinue the assessment activity if they chose to do so and knew that there was no risk of victimization. Participants willingly provided verbal consent before the assessment activity commenced.

For the sake of confidentiality and anonymity, the lecturer guaranteed participants that their names would be replaced by pseudonyms. Students who took part in the focus group for the empirical study were not coerced but considered participation as an opportunity to improve their performance.

\section{Data Collection}

The source of quantitative data was the rating scale on the analytic rubrics. The assessment criteria were descriptors of the levels of performance. Developmental assessment of participants' performance alerted participants of their weak performance. The scaffolding assessment activity with a set of three competences and assessment criteria engaged participants in a step-by-step process of demonstrating skills, knowledge, and capabilities in the educational studies course. The first phase examined participating students' abilities to collect information from a variety of written sources employing technology and was also an exhibit of knowledge of educational concepts and principles underpinning curriculum innovations in the context of educational transformation in South Africa and internationally. The performance descriptor for the foundational abilities was assessment criterion 1 (AC1).

The second phase focused on practical skills. The shreds of evidence of creative thinking, problem-solving, reflective practice, designing, and planning were to be performed by participants in utilizing the abilities developed from the foundational ability. Assessment criterion 2 (AC2) described the level of expected proficiency in the performance of skills.

The third phase examined the proficiency in the performance of reflexive competence, which entailed the ability to express attitudes and feelings, and create arguments and self-evaluation, and to give an account of good and bad professional practice in diverse situations and contexts. Assessment criterion 3 
(AC3) described the required standard or level of proficiency in the performance of the skills and abilities.

\section{Scaffolding assessment activity \\ First phase}

Foundational competence: students should demonstrate abilities to read sources critically, gather information, and to integrate conceptual knowledge across the education discipline.

Assessment criterion 1: the achievement of this competence will be evident when participants can: select relevant information or ideas, explain concepts, and connect conceptual knowledge of educational philosophical and theoretical principles.

\section{Second phase}

Practical competence: students should demonstrate abilities to relate philosophical and theoretical principles to the curriculum issues and work-related contexts.

Assessment criterion 2: the evidence of achievement of this competence will be in the demonstration of cognitive skills such as critical, creative, and analytic thinking.

\section{Third phase}

Reflexive competence: students should demonstrate abilities and skills of independent thinking, give an account of the choices of education philosophical principles and theories they recommend for their professional practice and to create arguments informed by their perspective of theories and philosophies.

Assessment criterion 3: the attainment of this competence will be evident when participants design learning and teaching activities for work-integrated learning, and when they conduct demo-classes and reflect on their practice.

\section{Data Analysis}

In this study, the focal context was the performance of the integrated competences in the assessment task by the entire participating class group. The quantitative data recorded in the frequency distribution of ratings on each criterion manifested four groupings summarized in the pie chart (Figure 1). The bar chart (Figure 2) presents quantitative data based on the rating scale of the performance of the three assessment criteria after the reflective task between the lecturer and the participants from the focus group displayed progress and improvement in the specific performance of the three assessment criteria.

The study also utilized a social constructivist research paradigm in which the researcher examines the perceptions and views of participants about their performance. The participants in the focus group had diverse learning needs in the respect that opportunities were afforded through the scaffolding assessment and continuous engagement with the lecturer to improve their performance. The first recordings of reflections were from the written template, which indicated the categories: feedback (what existing gaps are?), feed forward (what to attend to?), and feed up (what determines the optimal level of achievement?). Summaries in 
the grids classified under the categories of feedback, feed forward, and feed up are the reflections of participants on their performance.

\section{Presentation of Data}

The first set of data is presented in a pie chart in Figure 1. The figure illustrates the percentages gathered through the analysis of data, and the frequency distribution of the range of ratings of participants' performance indicates the varying levels. Participants in the sample demonstrated either weak, satisfactory, good, excellent, or outstanding performance.

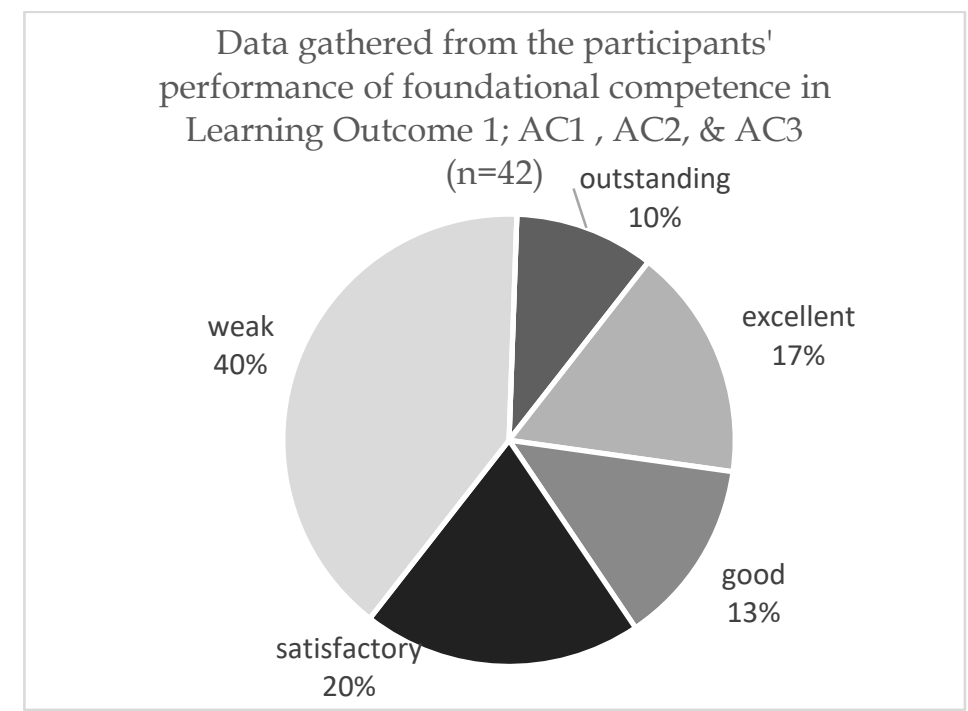

Figure 1. Data showing the grouping of the participants' levels of performance in percentages in the whole sample

The percentages reflected on the pie graph indicate that $40 \%$ of the participating pre-service teachers were not able to demonstrate competent performance of foundational abilities, skills, and knowledge. The satisfactory $20 \%$ of participants were of concern because their performance based on the descriptions of the rubrics indicated gaps and weak areas requiring support to improve their performance of critical skills, abilities, and knowledge.

\subsection{Data gathered from participants in the focus group through reflections}

The second set of data was from 25 students, $60 \%$ of the entire sample. These were student participants whose performance fell in the range of the weak and satisfactory categories on the rating scale. Participants' reflections on their performance guided by the descriptors on the analytic rubrics were provided to them during the first cycle of qualitative data analysis. The qualitative analysis of data focused on the participants' reflections on their abilities and skills to perform activities set to assess foundational competence (Table 1); AC1 of the assessment exercise. The coding of data during analysis was based on views participants expressed under the categories on the template, which were feedback, feed forward, and feed up. 
Table 1: Summary of participants' self-reflections based on the assessment of abilities, knowledge and skills to performance in foundational competence

\begin{tabular}{|c|c|c|}
\hline $\begin{array}{l}\text { Feedback identifying gaps } \\
\text { in the previous performance } \\
\text { (Where am I?) }\end{array}$ & $\begin{array}{l}\text { Feed forward } \\
\text { Required improvement } \\
\text { (What is next?) }\end{array}$ & $\begin{array}{l}\text { Feed up } \\
\text { (Where am I going?) }\end{array}$ \\
\hline $\begin{array}{l}\text { Acknowledgment of } \\
\text { shortcomings: } \\
\text { - Inadequate comprehension } \\
\text { of the task } \\
\text { - Disregarding the rubrics } \\
\text { - Definition of concepts } \\
\text { instead of critical reading } \\
\text { for comprehension } \\
\text { - Cut and pasted sentences } \\
\text { with no relevant meaning } \\
\text { to the assessment criteria }\end{array}$ & $\begin{array}{l}\text { Things considered to } \\
\text { improve performance: } \\
\text { - Understand the } \\
\text { description of the } \\
\text { competence and the } \\
\text { assessment criteria } \\
\text { - Information from } \\
\text { sources must be } \\
\text { understood with insight } \\
\text { - Compare philosophical } \\
\text { ideas and principles for } \\
\text { similarities and contrast }\end{array}$ & $\begin{array}{l}\text { The value of knowledge in } \\
\text { professional development: } \\
\text { - Professional teachers } \\
\text { should know, understand, } \\
\text { and realize that } \\
\text { philosophical principles } \\
\text { and theories are critical in } \\
\text { their professional practice } \\
\text { - Teachers are professional } \\
\text { practitioners who should } \\
\text { understand the } \\
\text { philosophical principles } \\
\text { underpinning the } \\
\text { curriculum design }\end{array}$ \\
\hline
\end{tabular}

The self-reflective exercise conducted by the participants highlighted the areas of development, as well as gaps in their knowledge, abilities, and skills that were expected in the previous assessment. Data also indicate that participants realized the levels of complexity of the foundational competence; hence, they listed the abilities, skills, and knowledge they require to achieve the optimal performance under feed forward and feed up. Data from the template which highlighted abilities, skills, and knowledge concerning practical application were classified under practical competence and AC2 during the process of data analysis (Table 2).

Table 2: Summary of participants' self-reflections based on the assessment of abilities, skills, and knowledge to performance in practical competence

\begin{tabular}{|c|c|c|}
\hline $\begin{array}{l}\text { Feedback identifying gaps in } \\
\text { the previous performance } \\
\text { (Where am I?) }\end{array}$ & $\begin{array}{l}\text { Feed forward } \\
\text { Required improvement } \\
\text { (What is next?) }\end{array}$ & $\begin{array}{l}\text { Feed up } \\
\text { (Where am I going?) }\end{array}$ \\
\hline $\begin{array}{l}\text { Acknowledgment of } \\
\text { shortcomings: } \\
\text { - The difficulty to link or } \\
\text { connect the information to } \\
\text { the practice } \\
\text { - Knowledge of philosophical } \\
\text { principles and theories was } \\
\text { not associated with } \\
\text { classroom practice } \\
\text { - Lack of understanding of } \\
\text { the significance of the } \\
\text { theoretical knowledge in } \\
\text { the professional application }\end{array}$ & $\begin{array}{l}\text { Things considered to } \\
\text { improve performance: } \\
\text { - Thinking of teaching } \\
\text { methods and teaching } \\
\text { approaches as part of } \\
\text { philosophical and } \\
\text { theoretical principles } \\
\text { - Relate philosophical } \\
\text { ideas when preparing } \\
\text { demo-lessons } \\
\text { - Read curriculum policy } \\
\text { documents to } \\
\text { understand } \\
\text { philosophical principles } \\
\text { underpinning it }\end{array}$ & $\begin{array}{l}\text { The value of knowledge in } \\
\text { professional } \\
\text { development: } \\
\text { - Conduct professional } \\
\text { practice underpinned by } \\
\text { the relevant philosophical } \\
\text { ideas of the society, for } \\
\text { example, democracy } \\
\text { - Integrate philosophical } \\
\text { and theoretical ideas in } \\
\text { classroom practice } \\
\text { - Plan and organize } \\
\text { scenarios that are relevant } \\
\text { to the philosophical ideas } \\
\text { of society }\end{array}$ \\
\hline
\end{tabular}


The comments under the feedback category point to the gaps participants declared as difficulties they experienced in applying knowledge in practice. The acknowledgment of the lack of abilities and skills to transfer knowledge to the real-life situation is of concern in the education and training of teachers because it could mean that students perceive theoretical and philosophical knowledge as unnecessary in their professional development and preparation for professional practice in the workplace.

The third set of data gathered from the template focused on reflexive competence. The self-reflection statements that indicated views related to awareness of attitudes, motivation, and ability to learn from current performance to effect changes were coded as reflexive statements (Table 3).

Table 3: Summary of participants' self-reflections based on the assessment of abilities, knowledge and skills to performance in reflexive competence

\begin{tabular}{|c|c|c|}
\hline $\begin{array}{l}\text { Feedback identifying gaps } \\
\text { in the previous } \\
\text { performance } \\
\text { (Where am I?) }\end{array}$ & $\begin{array}{l}\text { Feed forward } \\
\text { Required improvement } \\
\text { (What is next?) }\end{array}$ & $\begin{array}{l}\text { Feed up } \\
\text { (Where am I going?) }\end{array}$ \\
\hline $\begin{array}{l}\text { Acknowledgment of } \\
\text { shortcomings: } \\
\text { - Challenge was to create an } \\
\text { argument and present } \\
\text { interpretation from the } \\
\text { viewpoint of a student } \\
\text { - Challenge was to analyze } \\
\text { and interpret conceptual } \\
\text { knowledge of } \\
\text { philosophical foundations } \\
\text { and principles in } \\
\text { education } \\
\text { - It was not easy to } \\
\text { manipulate factual } \\
\text { knowledge to provide a } \\
\text { solution to the work- } \\
\text { related context } \\
\text { - Inability to link the } \\
\text { theoretical principles to } \\
\text { the context of professional } \\
\text { practice in the workplace }\end{array}$ & $\begin{array}{l}\text { Things considered to } \\
\text { improve performance: } \\
\text { - Select philosophical } \\
\text { ideas that are in my } \\
\text { view relevant to } \\
\text { improve strategies of } \\
\text { teaching or methods } \\
\text { - Seek approaches to } \\
\text { teaching as from } \\
\text { progressive } \\
\text { philosophical and } \\
\text { theoretical principles } \\
\text { when planning demo- } \\
\text { lesson in the micro- } \\
\text { teaching } \\
\text { - Relate and give account } \\
\text { for the choices of } \\
\text { philosophical principles } \\
\text { when preparing lessons } \\
\text { - Evaluate curriculum } \\
\text { policy documents to } \\
\text { understand } \\
\text { philosophical principles } \\
\text { underpinning it }\end{array}$ & $\begin{array}{l}\text { The value of knowledge } \\
\text { in professional } \\
\text { development: } \\
\text { - To be openminded } \\
\text { when reading } \\
\text { information about } \\
\text { professional practice } \\
\text { and philosophical ideas } \\
\text { of society } \\
\text { - Integrate social change } \\
\text { and philosophical } \\
\text { principles } \\
\text { - Comprehension of } \\
\text { philosophical ideas and } \\
\text { theories in education, } \\
\text { including pedagogy } \\
\text { relevant } \\
\text { - Integrate philosophical } \\
\text { and theoretical } \\
\text { constructs on classroom } \\
\text { practice }\end{array}$ \\
\hline
\end{tabular}

The categories of reflections in Table 3 highlighted issues and aspects that participants associated with their abilities and skills to integrate the understanding of knowledge with the application they were required to. 


\section{Presentation of qualitative data from verbal comments gathered during the post-assessment evaluation}

The patterns of thought that emerged from the face-to-face verbal comments highlighted that participants perceived the scaffolding assessment model of competences to be appropriate for their professional preparation. The selected comments linked to this claim are as follows:

"To be afforded another chance to improve my performance is wonderful to me. I have realized that doing this task step by step made me learn that the knowledge of what is linked with the knowledge of how and why. I find the comments from my lecturer helpful because of the suggestions made for improving $A C 1, A C 2$, and $A C 3 . "$ (Ramallah)

"I need to improve my ability to analyze information from sources. I will use the comments given by the lecturer to improve my performance of the assessment criteria 1, 2, and 3." (Thebius)

"This experience is a learning curve. In the beginning, I was confused because I am used to the writing of tests and essays. The assessment with phases, assessment criteria, and competences is a new experience. After understanding what competences and assessment criteria are, I became interested. I now know why my performance was weak." (Nolita)

"To be honest, I have gained experience and knowledge about the importance of philosophical principles and theories; I have an understanding of the value of this knowledge to my practice of teaching, and it was for the first time that I conducted self-reflections on my work. This approach is the best way of learning because it is more developmental than judgmental. The support and opportunity to improve on our errors help us to learn from our mistakes." (Zizi)

Some comments that presented a different view were also considered significant in the evaluation of this model:

"This approach to assessment is time-consuming compared to tests and examinations. I personally prefer a test, as long as I get a mark to pass the course." (Ralf)

"This assessment is for students who are interested in perfecting their knowledge. Some of us do not have such stamina. Multiple choice questions are my favorite because I memorize the factual knowledge and obtain distinction at that is all." (Sambo)

\subsection{Data gathered from summative assessment after formative assessment}

The final step of data gathering was the numerical coding of achievements. The variance between the first performance and the performance demonstrated by the group of 25 participants was evident in the final judgment of individual profiles of the first to the last attempts. Figure 2 illustrates the milestones achieved by participants after the interventions. 


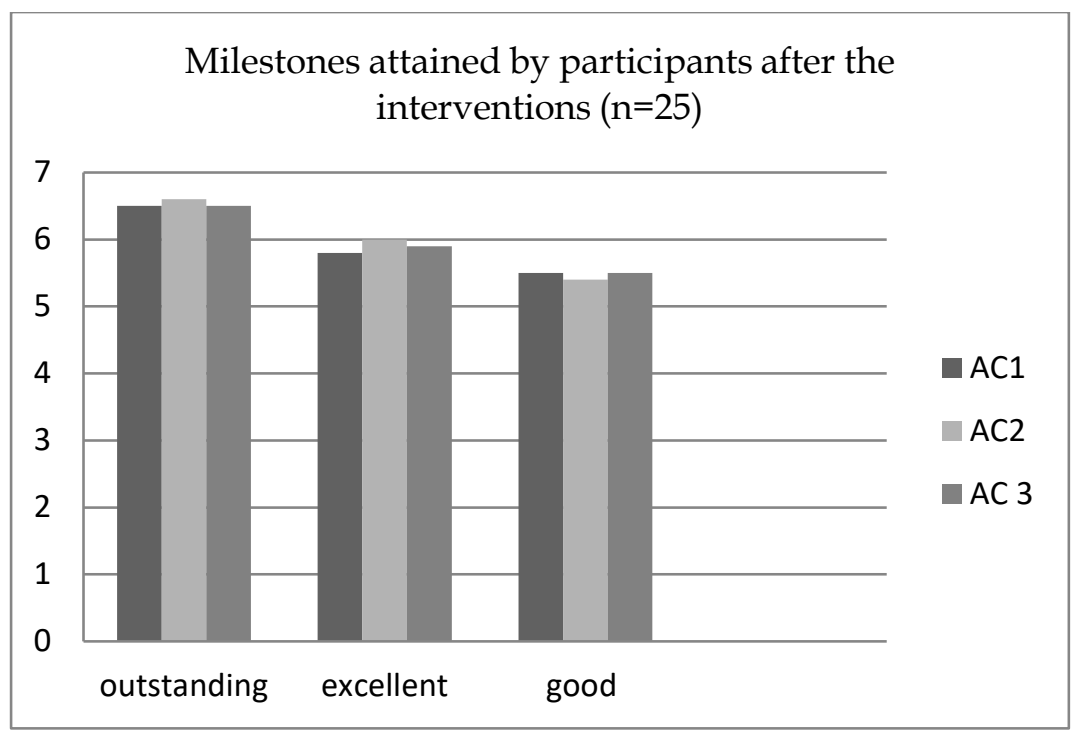

Figure 2. Performance of participants after the interventions and scaffolding instructions: Face-to-face verbal feedback, feed forward, and feed up

\section{Presentation of the Findings}

\section{Challenges experienced by students in the assessment of integrated} competences

The data displayed in figure 1 prove that $40 \%$ of the entire sample of 42 students demonstrated performance that was above the expected level of proficiency. In contrast, $60 \%$ of the participants performed below the standard in foundational, practical, and reflexive competences. This finding was critical in this study because it informed the lecturer of the kind and the intensity of support needed, and that monitoring was required to assist participants in the focus group.

The value of scaffolding assessment in the holistic development of competent professional teachers

The assessment of the three competences in one activity in a scaffolding model enabled the participants to first master foundational competence before engaging at the level of demonstrating the skills and abilities to contextualize the knowledge of principles in practice. The successful mastery of critical reading and reflective presentation indicated that participants attained proficiency in foundational competence. This competence forms the baseline for lifelong learning in the academic and professional development and growth. The skills for the practical application of the disciplinary and theoretical knowledge of principles encompassing professional functions and activities are critical in professional practice. The reflexive competence exposed participants to the zone of participating in knowledge construction. The participants who experienced difficulties in the three levels were identified and afforded opportunities to learn from their mistakes and to continue to improve those abilities and skills to the optimal level. The evidence of the improvement in the performance of the three competences highlighted in the bar chart (Figure 2) proved the efficacy of the scaffolding model in assessing integrated learning outcomes. These positive results in the context of initial (pre-service) teacher education and training could imply the necessity of shifting from the fixed timeframe for assessing learning to 
a more flexible timeframe. This will allow every student in the training course to attain the optimal level of proficiency in all three essential competences recommended as attributes for the competent teacher (SAQA, 2019).

\section{Experiences of self-regulatory learning and self-assessment}

The opportunity to engage in the reflective exercise enabled participants to know and understand the reasons for the rating of their performance on the foundational competence. The statements listed in the grid (Table 1) indicate that participants were able to realize that one of the mistakes they made was out of the attitude of negligence: "Inadequate comprehension of the task"; "Ignoring the performance descriptions on the analytic rubrics."

The reading and comprehension of instructions in the test and examination is a challenge to some students. Realization of the importance of reading instructions could lead to a change of the attitude of negligence. The interpretation given to the motivation, moreover the responsibility, demonstrated by participants in working independently, in the context of this article, was that competence-based assessment could be adopted and implemented to promote quality teachers. In the same breath, the issue that analytic rubrics and performance descriptors is not taken seriously by students proved to be a milestone in this study in discovering that participants realized that ignoring rubrics had a negative impact on their performance. The analytic rubrics and the rating scale were essential in the sense that they serve in describing the levels of performance for each assessment criterion (Killen, 2015). Cutting and pasting is a shortcut for students who do not want to read for comprehension and insight. The reflection that highlighted acknowledgment of plagiarism by participants was a positive finding in this work. The habit of cutting and pasting from sources without comprehension indicated improvement towards proficient professional and academic development.

The data presented in Tables 2 and 3 highlight a significant change in participants' perceptions of their education and training. Moreover, the realization of the importance of disciplinary and professional knowledge in the curriculum was associated with the following reflection:

"Selection of relevant philosophical ideas to improve the strategies of teaching or methods teaching proved the attainment of the proficiency level of reflexive competence; integrate philosophical and theoretical ideas on classroom practice and relate and give account for the choices of philosophical principles when preparing lessons."(Thebius)

Similarly, the comments coded during face-to-face verbal interactions with participants substantiated the view held in this work that scaffolding assessment is of value in assessment-integrated competences, and also in developing proficiency in the performance of professionals' practice of teaching students during their pre-service education and training.

"To be honest, I have gained a lot of knowledge about the significance of philosophical principles and theories; I have an understanding of the value of this knowledge to my practice of teaching and it was for the first time that I conducted self-reflections on my effort. This is the best way of 
learning because we were not judged but we received support and opportunity to improve on our errors." (Zizi)

The perception of the efficacy of scaffolding assessment expressed in the participant's verbal comment proved that assessment of competences should not be perceived to be an event but rather a process of gradual development and growth in the training of professionals. The attainment of proficiency levels by the cohort of students varied. Therefore, this implies that lecturers should consider multi-level abilities when planning and organizing assessment activities to supervise and monitor the development and growth of competent and professional teachers.

\section{Interpretation and Discussion of Findings}

The findings of the research presented in this work support the argument of international and local scholars that competence-based assessment improves the quality of preparing teachers for quality teaching and learning (Beets, 2009; Barnett, 2018). Furthermore, the findings provided a framework sought out by the researcher to plan and organize competence-based assessment activities that complement the policy promulgated in the SAQA (2019) guidelines. The findings enabled the researcher to establish the participating students' perspectives of the scaffolding model in the planning and organization of assessment activities.

The interactive engagement and non-judgmental attitudes observed and experienced by participants and the researcher during the process of assessment created an environment conducive to meaningful learning. Recognition and acknowledgment of gaps in knowledge, cognitive abilities, and skills against the expected level of proficiency were the evidence of the outcomes of the process of learning. Teachers in their pre-service training should develop these professional skills because they are expected to be reflective practitioners. The process of continuous professional development in the workplace is about innovative practice; therefore, the ability to recognize and acknowledge gaps while studying will enable teachers to be proactive and reflective practitioners.

The evidence of responsibility was interpreted as a signal of professional growth and development. According to the DHET (2019), the strength of integrating applied competences with teaching and learning and assessment lies in the development of a teacher who will be able to perform professional functions in diverse situations and contexts. A sense of commitment and responsibility demonstrated by participants indicated that they would be better able to apply skills, abilities, and knowledge competently in the classroom.

The evidence of responsibility observed from the reflective exercise and initiative to participate in the scaffolding assessment activity was interpreted as a sign of professional growth and development. The commitment to improving skills and abilities required to apply knowledge in different work-related situations and contexts was interpreted as the strength of integrating the three competences with teaching, learning, and assessment that lie in the development of a teacher who will be able to perform professional functions in diverse situations and contexts (SAQA, 2019). A sense of commitment and responsibility demonstrated by 
participants indicated that they would be better able to transfer and apply skills, abilities, and knowledge competently in the classroom. For their lifelong learning, participants developed a sense of greater responsibility and commitment to their education and training.

The shift in the perspective of assessment which emphasizes collecting marks from discrete assessment tasks to a consolidated activity with scaffolds was part of the learning experience for participants. In this regard, Nolitah commented:

"This is a learning curve. In the beginning, I was confused because I am used to the writing of tests and essays. The assessment with phases, assessment criteria, and competences is a new experience. After understanding what competences and assessment criteria are, I became interested. I now know why my performance was weak." (Ramalla)

The perception of assessment as the evidence that comes at the end of the learning process or to generate a summative record has no significant role in quality teaching and learning in the training of teachers to be competent practitioners. The findings of this research point out that students could develop different but related competences in the integrated process of teaching, learning, and assessment. In the process of assessment, the interactive engagement of students and lecturer provide a platform for learning and instruction. It is during this interactive engagement that students conduct the reflective exercise of feedback, feed forward, and feed up.

The findings of this research support the notion that competence-based education is an appropriate approach for integrating teaching, learning, and assessment. Boyer and Bucklew (2019) proposed that higher education should prepare students for the world of work, which has diverse demands and challenges. In the same vein, Barnett (2018) suggested that the programs for teacher education and training should consider a competence-based approach for equipping pre-service teachers with the knowledge of what, how, why and when. This research underscores the potential value of equipping pre-service teachers with professional skills and techniques, rather than with discrete pieces of information. This research proves that the scaffolding assessment activity can assess the abilities of pre-service teachers. This study supports the perspective that preservice teachers can work independently and responsibly if they have guidelines. This study also supports the perception of pre-service teacher education that promotes the integration of foundational competence (knowledge of factual knowledge), practical competence (knowledge of application), and reflexive competence (skills to reflect and evaluate) (SAQA, 2019). Professional practitioners should be prepared for lifelong learning, and this requires skills and expertise to practice their professional knowledge and doing so under various conditions (Lassnigg, 2018; Boyer \& Bucklew, 2019; Van Griethuijsen et al., 2019). As lifelong learners, their abilities and skills to think critically and creatively will enable pre-service teachers to comprehend challenges in the workplace and to adjust to the demands of the changing practices in education in the local as well as global context.

Competence-based assessment in pre-service teacher education and training provides the holistic evidence for students' abilities to comprehend the theoretical 
knowledge, its application, and to reflect on the changes when they are required (Barnett, 2018). The data in Tables 1, 2, and 3 provide a holistic view of the cognitive abilities and skills demonstrated by participating students at the basic level of proficiency concerning foundational competence. The value of selfreflection was the realization of specific areas of inadequacy and underdevelopment in the performance by the participants. According to Lassnigg (2018), self-reflection assists students to be aware of the areas of weakness in their performance in the process of professional development.

Development and growth in the teaching professions require the sound knowledge of theories and a high level of proficiency in critical thinking, logic, and reasoning skills (SAQA, 2019). The data presented in Tables 2 and 3, in the context of this paper, point to the value of competence-based assessment, as participants were able to realize that knowledge of philosophies and theories plays an important role in their professional practice in the real workplace. According to SAQA (2019), the pre-service teacher qualification curriculum should focus on the development of: foundational competence, practical competence, and reflexive competence, and the assessment should be integrated into high-stakes assessment tasks. The integrated assessment of competences through the scaffolding of activities enabled the participating students to understand that education and training are dual processes in teaching and learning and that the focus should shift from memorization and regurgitation of facts to meaningful learning of the what, how, when and why.

\section{Conclusion}

The data and the findings show that competence-based assessment proves to be an effective mechanism for enabling students to improve their performance of abilities, skills, and knowledge in the teaching discipline. The principles underpinning the transformation of initial (pre-service) teacher education and training point out that students in professional education and training should be competent in the general principles of the sound disciplinary knowledge base and application. In addition, they should be competent in the transfer of sound knowledge, and possess the ability to transfer and apply knowledge and skills in the real place of professional practice in different contexts and under diverse conditions (DHET, 2019, p. 51). The knowledge acquired from the scaffolding assessment activity is, firstly, that it is possible to assess more than one competence in a single activity; secondly, that analytic rubrics and the rating scale is the better tool for enabling interactive consultation between students and lecturer; and lastly, that the analytic rubrics can be used by students to profile their performance.

It was also concluded from the study that the principle of scaffolding assessment is to break the task into phases and that each phase should be allocated a flexible timeframe for all students to attain the optimal level of performance at their own pace. It was apparent during the assessment that students become easily discouraged when they experience difficulties to attain higher levels of proficiency in performing foundational competence. However, this attitude changed when the second and the third chance provided sufficient support and supervision. The scaffolding model proved to be efficacious in transforming the 
perception of competition to cooperation among students. The issue of re-testing was replaced by a remedial or re-engaging approach until achievement of the goal. The attitude in the assessment of attaining distinctions based on the number of ticks for the correct answers in the tests and exams was replaced by the profiling of competent performance in the cognitive skills and abilities, and practical and reflexive skills. This contributes to the holistically developed and assessed teacher.

Critical aspects in the application of the scaffolding assessment are, firstly, consistency, meaning that the remarks or comments concerning the indicators of proficient performance should be specific and precise to all students. Secondly, the issue of transparency and fairness play a great role in the establishment of trust and reliability. Transparency entails discussing the competences expected and abilities, skills, and knowledge assessed. Thirdly, the assessment criteria, which are the evidence required from students' performance, should be articulated explicitly. Fourthly, the rating scale and the rubrics describing the levels of proficiency should be discussed in a question and answer section to ensure that clarity prevails about what should be done.

The data and findings reported upon in this article attest to the fact that through scaffolding instruction and alignment of assessment criteria, it is possible to make valid and reliable judgments on the professional growth and development of students in their future teaching careers.

\section{Recommendations}

The findings of this article may motivate other researchers in higher education or teacher educators to use competence-based assessment as a better means of assessment. The findings reported on in this article are from a particular context that may not be similar in other institutions of higher learning and, therefore, may not be universally accepted. It is recommended that the findings in this article be understood in the context in which the study was conducted. However, this does not mean that these findings are not reliable; they can be used as a springboard for further research to transform traditional approaches to assessment in teacher education and training. The flexibility of timeframes in this study have proven to be of benefit to the development of students' academic abilities and professional skills. Therefore, this study recommends that teacher educators could consider this approach as an alternative means to afford students in teacher education and training opportunity for holistic academic and professional growth and development. 


\section{References}

Barnett, R. E. (2018). Assessment in higher education: An impossible mission? In D. Boud \& N. Falchikov (Eds.), Rethinking assessment in higher education learning for the long term (pp. 29-40). London: Routledge Falmer.

Beets, P. (2009). Towards integrated assessment in South African higher education. In E. Blitzer (Ed.), Higher education in South Africa: A scholarly look behind the scenes (Chapter 9, pp. 183-202). Stellenbosch: Sun Media.

Betts, L. R., Huntington, B., Lao L., Dillon, G. V., \& Baayard, P. (2019). Developing a competency-based education and training program for university tutors. The Journal of Competency-based Education, 4(4), 1-6. https://doi.org/10.1002/cbe2.1200

Black, P., \& Wiliam, D. (2014). Developing the theory of formative assessment. Educational Assessment, 21(1), 5-31.

Black, P., \& McCormick, R. (2010). Reflections and new directions. Assessment $\mathcal{E}$ Evaluation in Higher Education, 35(5), 493-499. https://doi.org/10.1080/02602938.2010.493696

Boyer, N., \& Bucklew, K. (2019). Competency-based education and higher education enterprise system. The Journal of Competency-Based Education, 4(1), 1-20. https://doi.org/10.1002/cbe2.1180

Cebrián, G., Junyent, M., \& Mulà, I. (2020). Competencies in education for sustainable development: Emerging teaching and research developments. Sustainability, 12(2), 579. https://doi.org/10.3390/su12020579

Crisp, G. (2012). Integrative assessment: Reframing assessment practice for current and future learning. Assessment and Evaluation in Higher Education, 37, 33-44. https:// doi.org/10.1080/02602938.2010.494234

Department of Higher Education and Training (DHET). (2019). Minimum requirements for teacher qualification. Pretoria: Government Printers.

Gessler, M., \& Peters, S. (2020). Competency-based education and training in Namibia: Educational transfer as an imitation. In M. Pilz \& J. Li (Eds.), Comparative Vocational Education Research (pp. 113-130). Wiesbaden: Springer. https://doi.org/10.1007/978-3-658-29924-8_7

Gulikers, J. T. M., Runhaar P., \& Mulder, M. (2018). An assessment innovation as a flywheel for changing teaching and learning. Journal of Vocational Education $\mathcal{E}$ Training, 70(2), 212-231. https:// doi.org/10.1080/13636820.2017.1394353

Killen, R. (2015). Teaching strategies for quality teaching and learning. Cape Town: Juta Publishers.

Lassnigg, L. (2018). Competence-based education and educational effectiveness. In M. Mulder (Ed.), Competence-based vocational and professional education: Bridging the worlds of work and education (pp. 667-693). Switzerland: Springer International Publishing.

MacMillan, J. H., \& Schumacher, S. (2018). Research in education: Evidence-based inquiry. New York: Pearson Inc.

Martinez, L. V., \& Hurtado, J. T. (2018). Competency-based evaluation in higher education: Design and use of competence rubrics by university educators. International Education Studies, 11(2), 118-131.

Misbah, Z., Gulikers, J. T. M., Dharma, S., \& Mulder, M. (2019). Evaluating competencebased vocational education in Indonesia, Journal of Vocational Education ETraining. https://doi.org/10.1080/13636820.2019.1635634

Navio, E. P., Dominguez, M. M., \& Zagalaz, J. C. (2019). Perception of the professional competence of last year's students of pre-primary education and primary 
education degrees and students of training teachers master. Journal of New Approaches in Education Research, 18(1), 58-65.

Ornstein, A. C., \& Hunkins, F. P. (2014). Curriculum: Foundations, principles, and issues. Harlow: Pearson Publishers.

Sayed, Y., \& Kanjee, A. (2013). Assessment policy in post-apartheid South Africa: Challenges for improving education quality and learning. Principles, Policy and Practice, 20(4), 444-469.

South African Qualifications Authority (SAQA). (2019). Guidelines for integrated assessment. Pretoria: Government Printers.

Van der Vleuten, C., Sluijsmans, D., \& Brinke B. D. (2017). Competence assessment as learner support in education. In M. Mulder (Ed.), Competence-based vocational and professional education (pp. 607-635). Switzerland: Springer.

Van Griethuijsen, R. A. L., Kunst, E. M., Van Woerkom, M., Wesselink, R., \& Poell, R. F. (2019). Does implementation of competence-based education mediate the impact of team learning on student satisfaction? Journal of Vocational Education \& Training. http:/ / doi.org/10.1080/13636820.2019.1644364

Watling, C. J., \& Ginsburg, S. (2018). Assessment, feedback, and alchemy of learning. Med Edu., 53(1), 76-85.

Wesselink, R. H., Biemans, J., Gulikers, J. T. M., \& Mulder, M. (2017). Models and principles for designing competence-based curricula, teaching, learning, and assessment. In M. Mulder (Ed.), Competence-based vocational and professional education: Bridging the worlds of work and education (pp. 533-553). Switzerland: Springer International Publishing.

Whalley, B. (2014). Teaching with assessment, feedback, and feed forward: Using 'preflight' to assist student achievement. In T. Bilham (Ed.), For the love of learning (pp. 1-14). Palgrave: MacMillan.

Woolfolk-Hoy, A. (2018). Educational psychology. New York: Pearson Inc. 


\section{APPENDIX A}

\section{High Stake Assessment Activity}

\begin{tabular}{|c|c|}
\hline \multirow[t]{2}{*}{$\begin{array}{l}\text { Foundational Competence: } \\
\text { In this activity should have } \\
\text { demonstrate conceptual knowledge of } \\
\text { traditional and progressive } \\
\text { philosophical ideas that influence } \\
\text { curriculum development } \\
\text { FOCUS } \\
\text { - Develop power point } \\
\text { presentation in at least } 8 \\
\text { slides to discuss the } \\
\text { knowledge of philosophies } \\
\text { and theories you have read } \\
\text { about from sources. } \\
\text { - Explain the philosophical } \\
\text { concepts, principles } \\
\text { underpinning educational } \\
\text { theories and practices. }\end{array}$} & $\begin{array}{l}\text { Assessment Criterion (AC1) } \\
\text { The indicators of the proficient } \\
\text { performance are: } \\
\text { - ability to collect information } \\
\text { from at least three different } \\
\text { sources } \\
\text { - Evaluate information for } \\
\text { relevance and appropriateness } \\
\text { to educational philosophies. } \\
\text { - Related information to the } \\
\text { theories you have learned about } \\
\text { from Psychology of education } \\
\text { - Present your discussion slides } \\
\text { using PowerPoint. Citation of } \\
\text { the sources consulted is } \\
\text { important. }\end{array}$ \\
\hline & \\
\hline $\begin{array}{l}\text { Practical Competence: } \\
\text { In this activity you should apply } \\
\text { conceptual knowledge of educational } \\
\text { philosophies and educational theories } \\
\text { from the field of psychology in the } \\
\text { context of professional practice } \\
\text { FOCUS } \\
\text { - Analyse four scenarios of the } \\
\text { classroom practices. } \\
\text { - Classify classroom practices on } \\
\text { the scenarios under traditional } \\
\text { and progressive philosophies } \\
\text { Explain the principles from } \\
\text { your knowledge of learning } \\
\text { theories ( Behaviourism, } \\
\text { Cognitive, Social } \\
\text { Constructivist, phenomenology, } \\
\text { Humanist) concerning the } \\
\text { connections between (i) the } \\
\text { learner and knowledge (ii) the } \\
\text { teacher and learner and (iii) } \\
\text { learning and learning } \\
\text { environment. }\end{array}$ & $\begin{array}{l}\text { Assessment Criterion (AC2) } \\
\text { The indicators of the proficient } \\
\text { performance are The indicators of the } \\
\text { proficient performance are: } \\
\text { - Ability to analyse information critical } \\
\text { and reflectively } \\
\text { - Ability to examine practices } \\
\text { displayed in the scenario and skill to } \\
\text { contrast and compare practices on } \\
\text { the scenario } \\
\text { - Skills align identified practices with } \\
\text { the principles from theories of } \\
\text { learning when reflecting on the } \\
\text { observed practices. }\end{array}$ \\
\hline
\end{tabular}




\begin{tabular}{|c|c|}
\hline $\begin{array}{l}\text { Reflexive Competence: } \\
\text { In this activity you are expected to } \\
\text { express your own opinion, experiences } \\
\text { and account of what the knowledge of } \\
\text { perspective in educational philosophies } \\
\text { and theories of learning for psychology } \\
\text { influence your thought about } \\
\text { professional practice } \\
\text { FOCUS } \\
\text { - Draw from your experiences } \\
\text { accumulated during school } \\
\text { based practice to evaluate the } \\
\text { value of you classroom practice } \\
\text { with specific reference to the } \\
\text { following: } \\
\text { (i) Strategies to teaching, } \\
\text { learning and classroom } \\
\text { management } \\
\text { (ii) Role of the teacher in the } \\
\text { classroom } \\
\text { (iii) planning and organising } \\
\text { learning content } \\
\text { Explain the philosophical ideas } \\
\text { and principles from educational } \\
\text { psychology which informed } \\
\text { your thoughts and opinions }\end{array}$ & $\begin{array}{l}\text { Assessment Criterions } \\
\text { The indicators of the proficient } \\
\text { performance are The indicators of the } \\
\text { proficient performance are: } \\
\text { - Ability to create the convincing } \\
\text { argument about the choice of } \\
\text { educational philosophies and } \\
\text { theories of learning. } \\
\text { - Skills in supporting presentation } \\
\text { with practical examples or } \\
\text { scenario from you previous, } \\
\text { general knowledge of } \\
\text { experiences from school based } \\
\text { practical learning } \\
\text { Defend your opinion by } \\
\text { comparing the traditional } \\
\text { practices in teaching profession } \\
\text { with progressive approaches } \\
\text { substantiating your argument } \\
\text { with factual knowledge from } \\
\text { sources }\end{array}$ \\
\hline THIRD PHASE & \\
\hline
\end{tabular}

\section{APPENDIXB}

The Rating Scale for Competences and Assessment Criteria

\begin{tabular}{|l|l|l|l|l|l|}
\hline Rating scale & & $\begin{array}{l}\text { Outstanding } \\
\text { performance }\end{array}$ & $\begin{array}{l}\text { Excellent } \\
\text { performance }\end{array}$ & $\begin{array}{l}\text { Good } \\
\text { performance }\end{array}$ & $\begin{array}{l}\text { Satisfactory } \\
\text { performance }\end{array}$ \\
\hline $\begin{array}{l}\text { Foundational } \\
\text { competence }\end{array}$ & AC1 & & & & \\
\hline $\begin{array}{l}\text { Practical } \\
\text { competence }\end{array}$ & AC2 & & & & \\
\hline $\begin{array}{l}\text { Reflexive } \\
\text { competence }\end{array}$ & AC3 & & & & \\
\end{tabular}

